\title{
Cold start emissions of passenger cars with gasoline and diesel engines in Real Driving Emissions tests
}

\begin{abstract}
Modernization of passenger cars and constant development of existing legislation lead to a reduction of exhaust emissions from these vehicles. In accordance with package 3 of the RDE test procedure, the European Commission has extended testing methods by including exhaust emissions during a cold start. The article compares the research results on the impact of ambient temperature during the cold start of spark-ignition and compression-ignition engines in road emission tests. The tests were carried out in line with the requirements of the RDE test procedure for passenger cars meeting the Euro 6d-Temp emissions standard. The obtained results were analyzed, i.e. there were compared the engine and vehicle operation parameters and the values of road exhaust emissions, during the cold start of gasoline and diesel engines at the ambient temperature of approximately $25^{\circ} \mathrm{C}$. The summary presents the share of cold start phase of a passenger car (at the ambient temperature of around $25^{\circ} \mathrm{C}$ ) for each exhaust emission compound in the urban part of the test, and in the entire RDE test, depending on the engine type used.
\end{abstract}

Key words: exhaust emission, passenger cars, Real Driving Emissions

\section{Introduction}

Despite constant changes in legislation, road transport is still considered the most important source of hydrocarbons, carbon monoxide, carbon dioxide, nitrogen oxides, and particulate matter emissions. These compounds cause not only the deterioration of air quality but also the human health condition. This effect is particularly visible in many urban areas. It has led legislators to adopt more stringent pollutant emission standards for the automotive sector worldwide [17]. For example, by 2021 the limits on carbon dioxide emissions will have been reduced to $95 \mathrm{~g} / \mathrm{km}$. Unfortunately, the growing number of passenger cars moving within the European Union is becoming a real issue. That is the reason to develop better key emission control strategies.

The analysis of the cold start emissions level is particularly important because it is perceptible mainly in urban areas where it is the immediate vicinity of people. In recent years, many publications about the impact of ambient temperature on exhaust emissions during a cold start have been published. The impact of low ambient temperatures on pollutant emissions in lab tests has been described in detail. Already in 2011, the authors of the article [1] noticed the problem of cold start at low ambient temperatures. The objects of their research were both gasoline and diesel engines meeting the Euro 4 and Euro 5 emission standards in the NEDC test (at ambient temperatures of $24^{\circ} \mathrm{C}$ and $-7^{\circ} \mathrm{C}$ ). They pointed out that if the oil and coolant temperatures are equal or close to ambient temperature, starting up an engine, with no apparent increase in pollutant emissions and increased fuel consumption, may be more difficult to obtain (especially at low ambient temperatures). The authors of the article [16] came to the same conclusions but for the next generation of emission standards, i.e. Euro 6. The authors of article [14] determined the impact of various ambient temperatures $\left(-7^{\circ} \mathrm{C}\right.$ and $\left.23^{\circ} \mathrm{C}\right)$ on the emission results of vehicles equipped with compression and spark ignition engines. The aim of the test was to verify the results according to Euro 6 standards and check if the exhaust emis- sions in WLTC test increase during the cold season in comparison to higher ambient temperatures. The authors focused on determining the effect of an ambient temperature on exhaust emissions in the entire WLTC test, and not only during the cold start period. The research results indicated that the tested vehicles (at the ambient temperature of $23^{\circ} \mathrm{C}$ ) were in line with type approval of Euro 6 vehicles (still using NEDC), with the exception of $\mathrm{NO}_{\mathrm{x}}$ emissions from diesel vehicles that were 2.3-6 times higher than Euro 6 standards. Lowering the ambient temperature to $-7^{\circ} \mathrm{C}$ caused a significant increase in exhaust emissions from the tested vehicles. The largest differences in the $\mathrm{CO}$ and THC emission values were observed for the spark-ignition engine at two different ambient temperatures. The authors of this article noticed the need to develop a new and independent procedure allowing verification of the emissions level at low ambient temperatures.

It is worth noticing that approval tests carried out in laboratory conditions (on a chassis dynamometer) are not sufficient. They have been introduced as a complementary exhaust emissions testing in real traffic conditions [10, 13]. The research on exhaust emissions from transport vehicles in conditions of real operation reflect the actual ecological performance of vehicles [7-9]. Their results showed an increased emission of some exhaust components and particulates in comparison to tests carried out in laboratory conditions [12, 15]. The authors of the publication [11] determined the impact of two different ambient temperatures $\left(8^{\circ} \mathrm{C}\right.$ and $\left.25^{\circ} \mathrm{C}\right)$ during the cold start of a sparkignition engine in emission road tests. They defined the share of the cold start phases for different ambient temperatures in the entire RDE test, but also in the urban part of the RDE test. The share of the cold start in the urban part of RDE test is the highest at the temperature of $8^{\circ} \mathrm{C}$. The values are as follows: $\mathrm{CO}_{2}(11.6 \%)$ and $3.4 \%$ (the entire RDE test), $\mathrm{CO}(26 \%), \mathrm{NO}_{\mathrm{x}}(10.6 \%), \mathrm{PM}(22.7 \%)$. The share of the cold start at the temperature of $25^{\circ} \mathrm{C}$ in the urban part of 
the RDE test is as follows: $\mathrm{CO}_{2}(9.8 \%), \mathrm{CO}(10.6 \%), \mathrm{NO}_{\mathrm{x}}$ (12.3\%), PM (18.4\%).

This article is an extension of the publication [11]. The aim of this article is to compare the share of a cold start phase of a passenger car (at one ambient temperature around $25^{\circ} \mathrm{C}$ ) for each exhaust emission compound in the urban part of the test, and in the entire RDE test, depending on the engine type used (gasoline or diesel).

\section{Requirements of RDE tests}

The RDE test needs to meet a lot of requirements which have listed in Fig. 1. The test is divided into three sections: urban, rural and motorway conditions. The test drive is carried out continuously. The rural drive section can be interrupted by short periods of urban driving if urban areas are on the route. Driving on the motorway can interrupt short driving periods in urban or rural areas. The duration of the test is within the acceptable range, i.e. from 90 minutes to 120 minutes.

\begin{tabular}{|c|c|c|c|}
\hline Requirements & Urban & Rural & Motorway \\
\hline Vehicle speed & $0-60 \mathrm{~km} / \mathrm{h}$ & $60-90 \mathrm{~km} / \mathrm{h}$ & $90-145 \mathrm{~km} / \mathrm{h}$ \\
\hline Distance share & $29-44 \%$ & $23-43 \%$ & $23-43 \%$ \\
\hline Min distance & $16 \mathrm{~km}$ & $16 \mathrm{~km}$ & $16 \mathrm{~km}$ \\
\hline Average speed & $15-40 \mathrm{~km} / \mathrm{h}$ & - & - \\
\hline Total stop time & $6-30 \%$ & - & - \\
\hline Individual stop time & $\leq 300 \mathrm{~s}$ & - & - \\
\hline$V>100 \mathrm{~km} / \mathrm{h}$ & - & - & $\geq 5 \mathrm{~min}$ \\
\hline$V>145 \mathrm{~km} / \mathrm{h}$ & - & - & $<3 \% \mathrm{~m}_{\text {time }}{ }^{*}$ \\
\hline \multicolumn{4}{|c|}{ 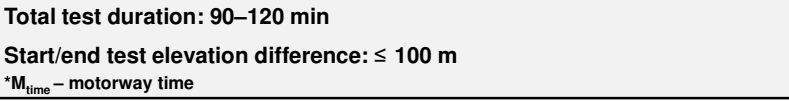 } \\
\hline
\end{tabular}

Fig. 1. The RDE test requirements [2-5]

Package 3 of the RDE test procedure have introduced among others the inclusion of cold start period emissions in the whole RDE test. Cold start is the period from the first start of combustion engine until the point when the combustion engine has run cumulative for $5 \mathrm{~min}$. The cold start period ends once the coolant temperature has reached $70^{\circ} \mathrm{C}$ for the first time but no later than after $5 \mathrm{~min}$ from initial engine start [6]. The requirements for cold start are listed in Fig. 2.

\begin{tabular}{|c|}
\hline REQUIREMENTS FOR COLD START \\
\hline Max vehicle speed $\leq 60 \mathrm{~km} / \mathrm{h}$ \\
\hline Average vehicle speed (including stops) $15-40 \mathrm{~km} / \mathrm{h}$ \\
\hline Total stop time $<90 \mathrm{~s}$ \\
\hline Idling after ignition $15 \mathrm{~s}$ \\
\hline $\begin{array}{c}\text { Idling after vehicle conditioning for cold start } \\
\text { testing driven for at least } 30 \text { min followed by soak } \\
\text { duration in the range of } 6 \text { to } 56 \text { hours }\end{array}$ \\
\hline \\
\hline
\end{tabular}

Fig. 2. Cold start requirements [6]

\section{Research methodology}

The study consisted of the pollutant emissions comparison and describing the relations between test results at the ambient temperature of $25^{\circ} \mathrm{C}$. Before the road test, the vehicles were conditioned at ambient temperature for 24 hours. Accordingly, the engine oil and engine coolant temperatures corresponded to ambient temperature, so the requirement of a cold engine start (taking into account the appropriate ambient temperature) was met.

\section{Research objects}

During the tests, there were used passenger cars of the same brand with the curb weight of approximately $1450 \mathrm{~kg}$ and Euro 6d-Temp emissions standard (vehicles approved in accordance with the WLTP procedure). The first one was equipped with a gasoline engine and the second one with a diesel engine. Both engines were turbocharged. The engine displacement was $1.6 \mathrm{dm}^{3}$, the maximum power was $130 \mathrm{~kW}$ and $125 \mathrm{~kW}$ respectively, and the maximum torque was $300 \mathrm{Nm}$ and $350 \mathrm{Nm}$ respectively. In the case of the gasoline engine, the exhaust aftertreatment system was a three-way catalytic converter with a particulate filter, and in the case of the diesel engine, there were an oxidation reactor, a selective catalytic reduction system and a particulate filter. The choice of such research objects was dictated by the fulfillment of requirements relating to RDE tests.

\section{Research apparatus}

Emission measurements were carried out in real driving conditions; this approach requires the installation of the gas sampling apparatus on the vehicle in such a way that ensures its normal operation. Therefore, a gas sampling system was prepared, which together with the system measuring the flow rate of the exhaust gas also performed partial sampling of the flue gas for the analyzers to enable making the measurement (Figure 3 shows the wiring schematic of the measuring equipment).

a)

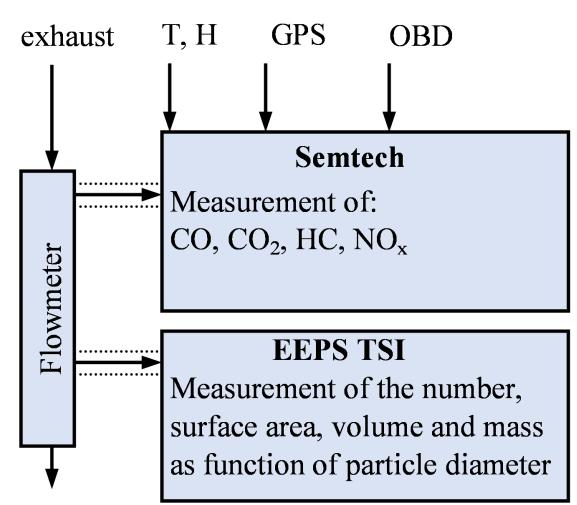

b)

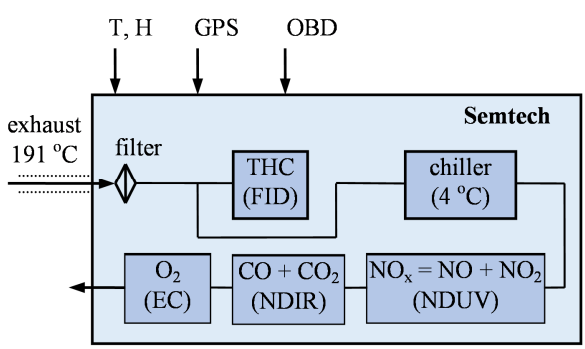

Fig. 3. Diagram of the measurement system used for testing (a) and mobile exhaust gas analyzer with marked flue gas flow (b) for the measurement of gaseous compounds and particulates; $\mathrm{T}$ - ambient temperature, $\mathrm{H}$ - air humidity 


\section{Research route}

The research route was designated in accordance with the RDE requirements and divided into 3 parts: urban, rural and motorway (Fig. 4). The lengths and shares of individual parts were in line with the requirements specified in EU standards EU 2016/427 [3] and EU 2016/646 [4]. The test distance was about $90 \mathrm{~km}$, and the average velocity during the test was around $45 \mathrm{~km} / \mathrm{h}$. The test was repeated twice for two vehicles with different type of engine (gasoline and diesel).

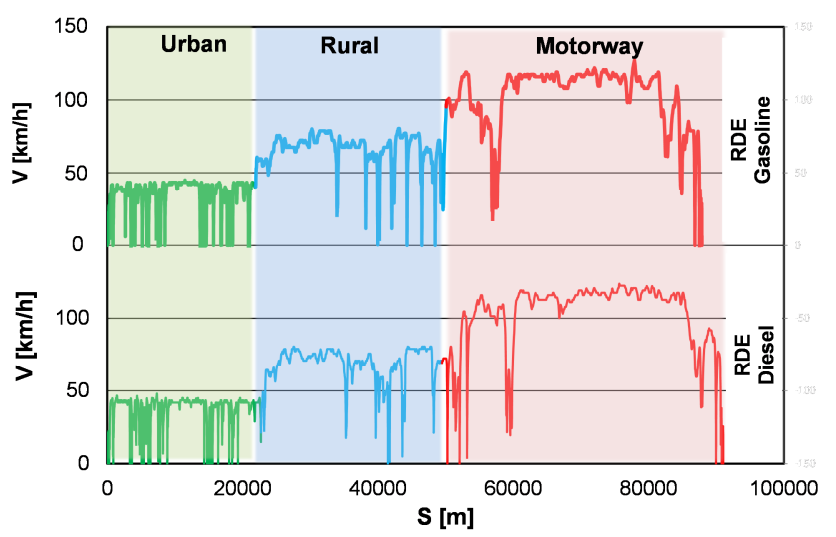

Fig. 4. Velocity of individual test drives

\section{The analysis of recorded parameters}

Operating parameters of an engine (a vehicle)

The first stage of the study was to check the validity of performing road tests, which are specified in the Regulations $[3,4,6]$, mainly concerning the length of individual road test phases and shares in the entire test, the test duration, the share of stops in the urban part, and driving dynamics in particular parts of the RDE test. All parameters were verified by appropriate procedures and no deviations from the required values were found (Tab. 1). For a reliable comparison, there was also carried out an analysis regarding the similarity of test drives.

Therefore, the characteristics of the individual driving stages duration in the velocity-acceleration co-ordinates for vehicles equipped with a spark-ignition engine and a compression-ignition engine were made. This comparison shows (Fig. 5) that there is a large similarity of test drives.

a)

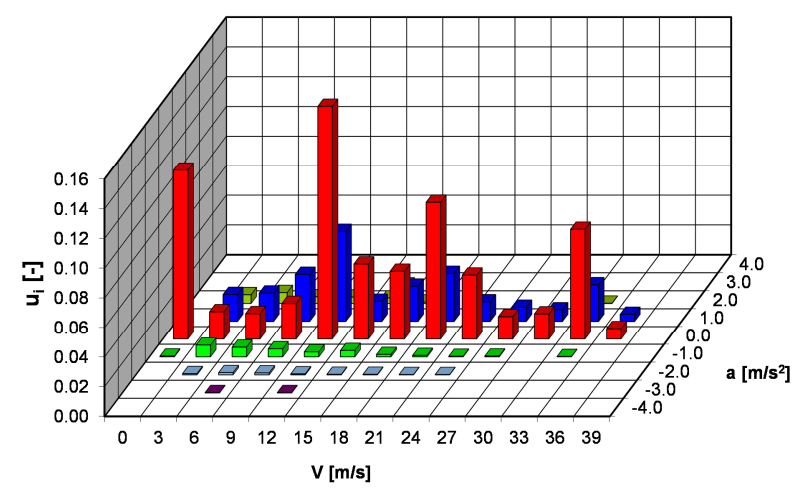

b)

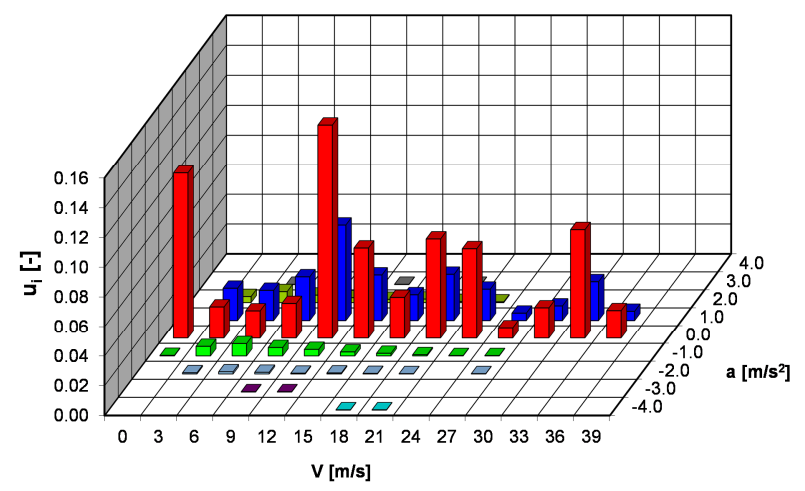

Fig. 5. The characteristics of vehicle operating time share in the velocityacceleration co-ordinates for gasoline engine (a) and diesel engine (b)

Table 1. Validation of trip characteristics in accordance with EU RDE requirements

\begin{tabular}{|c|c|c|c|c|}
\hline Trip characteristics & Gasoline & Diesel & Requirement & Valid? \\
\hline Urban distance $[\mathrm{km}]$ & 29.9 & 30.5 & $>16$ & $\mathrm{OK}$ \\
\hline Rural distance [km] & 28.1 & 27.9 & $>16$ & $\mathrm{OK}$ \\
\hline Motorway distance $[\mathrm{km}]$ & 29.9 & 32.6 & $>16$ & OK \\
\hline Total trip distance $[\mathrm{km}]$ & 87.9 & 91.0 & $>48$ & $\mathrm{OK}$ \\
\hline Urban distance share [\%] & 34.1 & 33.5 & $29-44$ & OK \\
\hline Rural distance share [\%] & 31.9 & 30.7 & $33 \pm 10$ & $\mathrm{OK}$ \\
\hline Motorway distance share [\%] & 34.0 & 35.8 & $33 \pm 10$ & OK \\
\hline Urban average speed $[\mathrm{km} / \mathrm{h}]$ & 27.6 & 27.6 & $15-40$ & $\mathrm{OK}$ \\
\hline Urban stop time [\%] & 19.8 & 19.1 & $6-30$ & OK \\
\hline Motorway speed above $100 \mathrm{~km} / \mathrm{h}$ [min] & 13.4 & 16.0 & $>5$ & OK \\
\hline Motorway speed $\max [\mathrm{km} / \mathrm{h}]$ & 127.2 & 123.8 & $<160$ & OK \\
\hline Motorway speed above $145 \mathrm{~km} / \mathrm{h}[\%]$ & 0.0 & 0.0 & $<3$ & OK \\
\hline Total trip duration [min] & 104.7 & 106.6 & $90-120$ & OK \\
\hline \multicolumn{5}{|c|}{ Cold start requirements } \\
\hline Cooling temperature $\left[{ }^{\circ} \mathrm{C}\right]$ & 67.0 & 59.0 & $<70$ & $\mathrm{OK}$ \\
\hline Max vehicle speed $[\mathrm{km} / \mathrm{h}]$ & 41.9 & 46.7 & $<60$ & OK \\
\hline Stop time $[\mathrm{s}]$ & 36 & 37 & $<90$ & OK \\
\hline Idling after ignition [s] & 8 & 6 & $<15$ & $\mathrm{OK}$ \\
\hline \multicolumn{5}{|c|}{ Overall trip dynamics } \\
\hline Urban 95th percentile $\mathrm{V} \cdot \mathrm{a}_{+}\left[\mathrm{m}^{2} / \mathrm{s}^{3}\right]$ & 12.9 & 12.3 & $<18.198 /<18.228$ & $\mathrm{OK}$ \\
\hline Rural 95th percentile $\mathrm{V} \cdot \mathrm{a}_{+}\left[\mathrm{m}^{2} / \mathrm{s}^{3}\right]$ & 13.8 & 17.2 & $<24.166 /<24.361$ & $\mathrm{OK}$ \\
\hline Motorway 95 th percentile $\mathrm{V} \cdot \mathrm{a}_{+}\left[\mathrm{m}^{2} / \mathrm{s}^{3}\right]$ & 15.4 & 14.7 & $<27.194 /<27.304$ & OK \\
\hline Urban RPA $\left[\mathrm{m} / \mathrm{s}^{2}\right]$ & 0.14 & 0.15 & $>0.131 />0.131$ & $\mathrm{OK}$ \\
\hline Rural RPA $\left[\mathrm{m} / \mathrm{s}^{2}\right]$ & 0.070 & 0.073 & $>0.061 />0.059$ & OK \\
\hline Motorway RPA $\left[\mathrm{m} / \mathrm{s}^{2}\right]$ & 0.070 & 0.048 & $>0.025 />0.025$ & OK \\
\hline
\end{tabular}


The possibility of comparing the results of exhaust emissions in road tests is valid only in the case of test drives similarity. Road tests are characterized by high uniqueness of road conditions, despite meeting the formal requirements presented above. The definition of test performance correctness, described by relative positive acceleration or the product of vehicle velocity and positive acceleration, may not be sufficient to confirm the comparability of results obtained in road tests.

Comparison of the vehicle operating conditions can be made on the basis of two-dimensional characteristics of vehicle operation. For this purpose, the relevant shares of vehicle operating time are compared on the twodimensional characteristics. In this way, two data columns are obtained that will be used to determine the regression equation $(y=a x+b)$. The determination coefficient $\left(R^{2}\right)$ is a measure on the basis of which the test drives can be compared. The compared data is similar if the straight-line coefficient is close to 1 (assuming that the value of constant term is equal to 0). Such comparison is presented in Fig. 6, where the entire RDE test, urban, rural and motorway sections of RDE test are collated (for the vehicle with sparkignition engine and the compression-ignition engine). The obtained values of the determination coefficient are close to the value of 1 , which means high compatibility between the obtained operating conditions of both vehicles in RDE tests.

However, the most important was to check the correctness of the cold start parameters and initial conditions of the road test start (these parameters are discussed in the introduction). For this reason, the vehicle velocity analysis during the cold start period (Fig. 7) has been made. It is required to start driving after a maximum of 15 seconds from starting the engine. This condition was met in both cases and at the same time a similar character of the vehicle velocity changes is observed in the first $300 \mathrm{~s}$ of the RDE (slightly higher values of the average vehicle velocity were recorded for the vehicle equipped with a diesel engine).

The comparison of the coolant temperature in both cases also shows that the requirements of the RDE test procedure have been met, as it did not exceed $70^{\circ} \mathrm{C}$. During the gasoline engine tests, $300 \mathrm{~s}$ from the engine start, the coolant temperature was $67^{\circ} \mathrm{C}$, and for the vehicle fitted with the diesel engine the temperature was only $62^{\circ} \mathrm{C}$. The initial temperature difference between the engine coolant in both type of engines was at the value of $1{ }^{\circ} \mathrm{C}$, and after $300 \mathrm{~s}$ (since the engine was started) it increased to $5^{\circ} \mathrm{C}$ (Fig. 8).

A similar character of changes was also observed during the analysis of exhaust temperature, measured at the end of the vehicle exhaust system (Fig. 9). The difference occurring for the measurement time $(\mathrm{t}=0)$ of around $3^{\circ} \mathrm{C}$ is compensated already after $20 \mathrm{~s}$, where the exhaust temperature is about $20^{\circ} \mathrm{C}$. The further course of exhaust temperature changes (up to $\mathrm{t}=200 \mathrm{~s}$ ) is very similar to each other (exhaust temperature around $40^{\circ} \mathrm{C}$ ) and the occurring differences in this period are very small $\left( \pm 5^{\circ} \mathrm{C}\right)$. However, the last $100 \mathrm{~s}$ of the period are different - for the gasoline engine the exhaust temperature rises to $47^{\circ} \mathrm{C}$, and for the diesel engine it decreases to $36^{\circ} \mathrm{C}$.
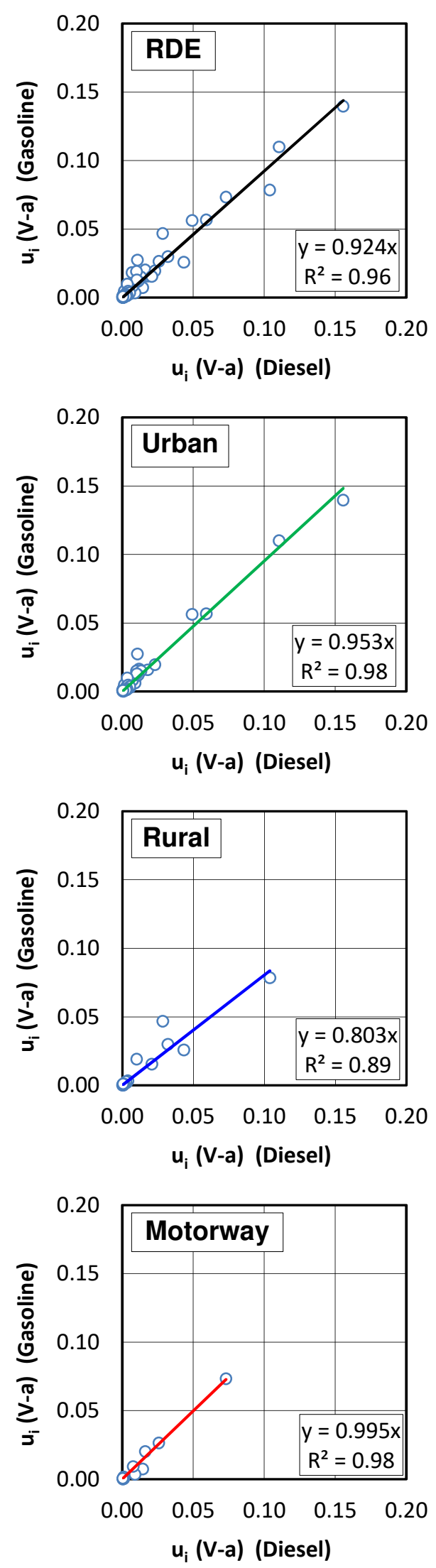

Fig. 6. Comparison of the test drives compliance (vehicles with gasoline engine and diesel engine) with the use of linear correlation of vehicle operating time share in each velocity and acceleration compartment 


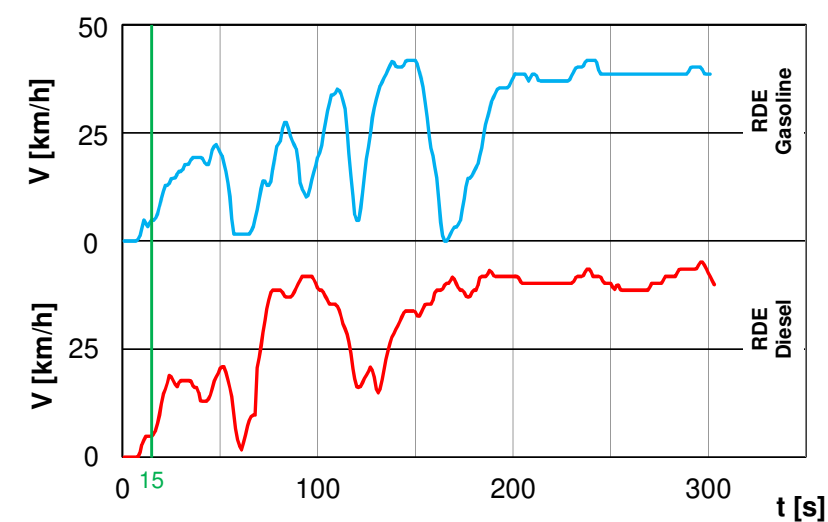

Fig. 7. The vehicles velocity during the phase of the engine cold start

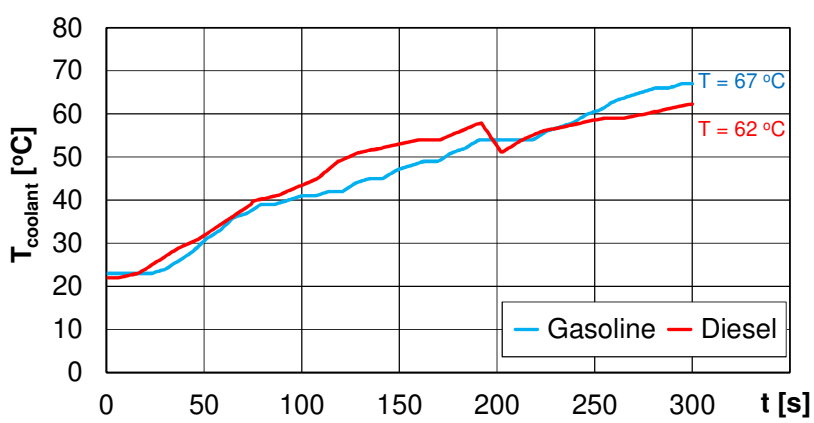

Fig. 8. The coolant temperature during the cold start phase of the gasoline and diesel engines

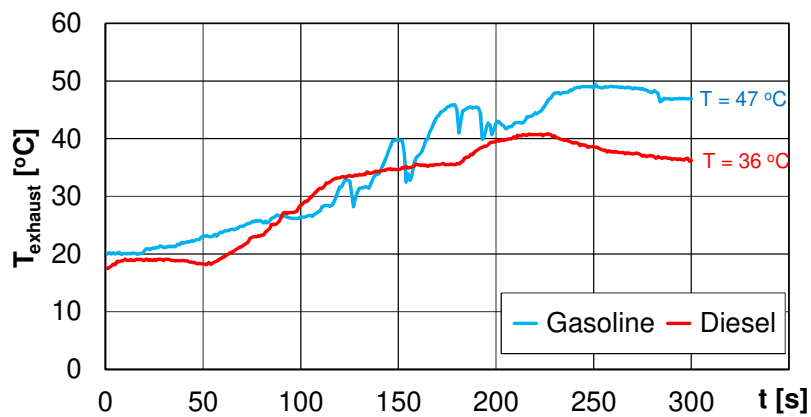

Fig. 9. The exhaust temperature during the cold start phase of the gasoline and diesel engines

The presented analysis of selected engine operating parameters allowed to find the similarity of engine operation conditions (and vehicles), and the element differentiating both measurements is the type of engine used in tests. On this basis, it was reasonable to take further actions that will answer the question about differences in concentration and emission of exhaust compounds in the initial period of vehicle operation (equipped with a different type of combustion engine).

\section{Ecological parameters}

The recorded course of exhaust concentration changes in the first period $(\mathrm{t}=0-300 \mathrm{~s})$ of the cold start phase for gasoline and diesel engines are presented below.

The analysis of carbon dioxide concentration (Fig. 10) shows that during the cold start and warming the engine, the average concentration of this compound was about twice smaller for the compression-ignition engine $(7.6 \%)$ compared to the spark-ignition engine $(14.3 \%)$. Slight fluctuations from the value set for the spark-ignition engine were the result of a change in the vehicle velocity - changes in the dynamic motion conditions. However, the average value of this parameter is not affected by the ambient temperature at which the cold engine started. For the compression-ignition engine, the course of changes in the carbon dioxide concentration was in the range of $4 \%$ to $12 \%$, and resulted mainly from the change of the instantaneous engine load.
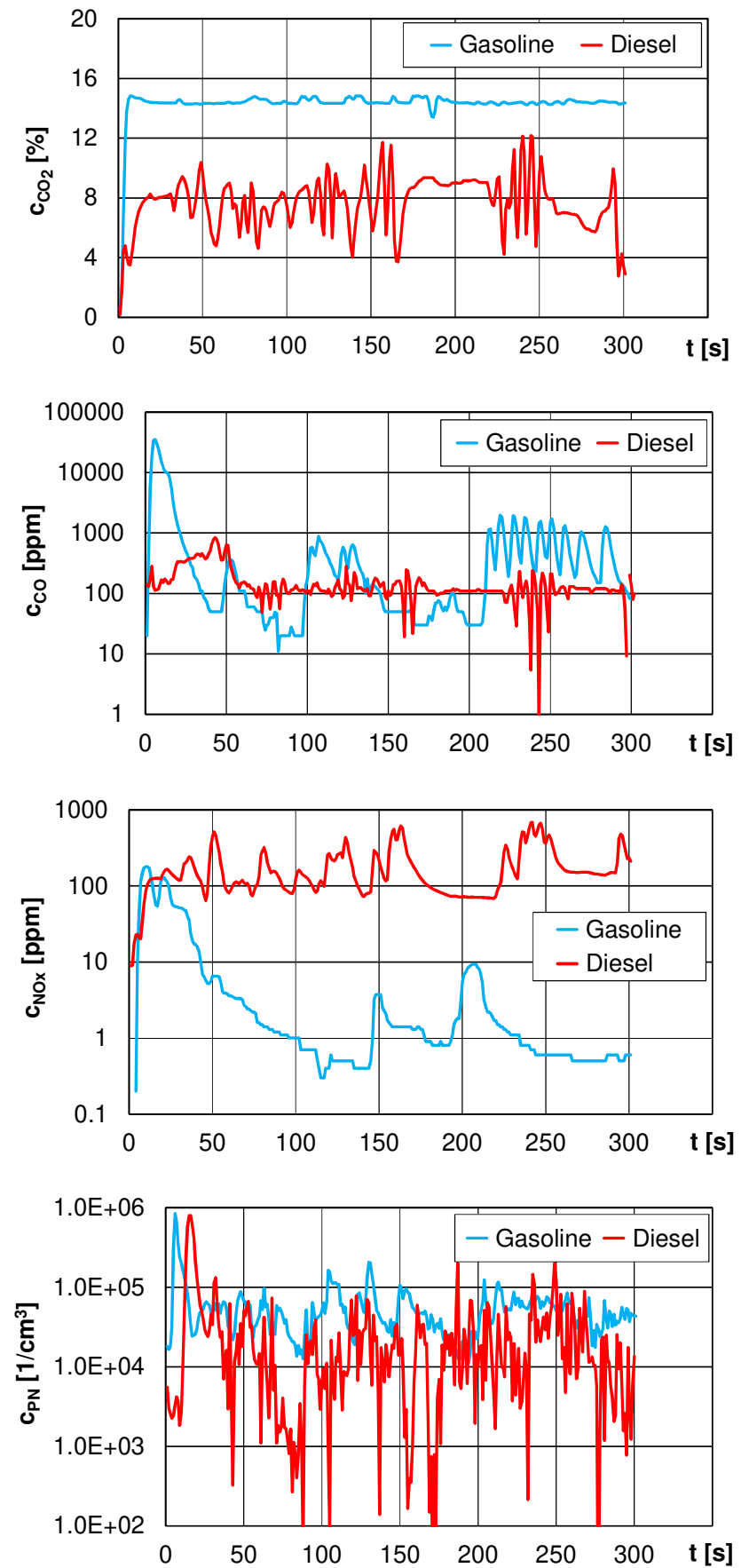

Fig. 10. The change of exhaust gases concentration during $300 \mathrm{~s}$ from the cold start for gasoline and diesel engines: carbon dioxide, carbon monoxide, nitrogen oxides, and particles number 
The course of changes in the carbon monoxide concentration is different in nature. The characteristic instantaneous increase in the concentration during the cold start phase of gasoline engine reaches the value of about 30,000 ppm, however it drops very quickly to $50 \mathrm{ppm}$. This reduction occurs in the value of about $50 \mathrm{~s}$. Then there is a change in concentration in the range of 100-1000 ppm caused mainly by the change of the engine load. In the case of diesel engine cold start, the values of carbon monoxide concentration are much lower. The first increase of this compound after engine start is around the value of $1000 \mathrm{ppm}$, and then the concentration oscillates about the value of $100 \mathrm{ppm}$. Therefore, the carbon monoxide emission intensity should increase significantly in the first period of the gasoline engine cold start phase in comparison to the diesel engine.

The concentration of nitrogen oxides is different from the analysis of the previous compound. For the gasoline engine cold start phase, an increased concentration of nitrogen oxides (up to $100-150 \mathrm{ppm}$ ) is observed only in the initial phase (within the first $50 \mathrm{~s}$ after starting the engine). In the $50^{\text {th }}$ second of the RDE test, the value of nitrogen oxides concentration for the gasoline engine is 10 times lower than for diesel engine. After time of $100 \mathrm{~s}$, the concentration of nitrogen oxides is 100 -fold lower for gasoline engine in comparison to diesel engine. For the diesel engine, the concentration of $\mathrm{NO}_{\mathrm{x}}$ was remained at the level of 100-1000 ppm throughout the whole period considered, while for the gasoline engine it did not exceed $10 \mathrm{ppm}$.

Regarding the particles number, there were observed higher values for the gasoline cold start $\left(1.0 \cdot 10^{4} 1 / \mathrm{cm}^{3}-\right.$ $\left.1.0 \cdot 10^{5} 1 / \mathrm{cm}^{3}\right)$ in comparison to the diesel engine $\left(1.0 \cdot 10^{2} 1 / \mathrm{cm}^{3}-1.0 \cdot 10^{5} 1 / \mathrm{cm}^{3}\right)$. The average value of the particulate matter concentration for the gasoline engine in the considered period of $300 \mathrm{~s}$ was $5.9 \cdot 10^{5} 1 / \mathrm{cm}^{3}$, and for the diesel engine $3.4 \cdot 10^{4} 1 / \mathrm{cm}^{3}$. After about $230 \mathrm{~s}$ from the cold start, the number concentration of particles in both cases stabilized at $1 \cdot 10^{4} 1 / \mathrm{cm}^{3}$.

\section{Analysis of test results regarding the engine cold start phase}

Taking into account the exhaust mass flow rate, a quantitative evaluation of the exhaust emissions was made in the period of $300 \mathrm{~s}$ from the starting of the gasoline and diesel engines (Fig. 11). In the case of carbon dioxide mass, it is higher by 2 times (after $300 \mathrm{~s}$ from engine start) for the gasoline engine than for the diesel engine. When the measurement was related to the gasoline engine, the carbon dioxide mass was $677 \mathrm{~g}$, for the diesel engine the mass was equal to $312 \mathrm{~g}$.

The carbon monoxide mass during the $300 \mathrm{~s}$ period of the gasoline engine cold start was $3.45 \mathrm{~g}$, and for the diesel engine it was 23 times lower and amounted to $0.14 \mathrm{~g}$. The nitrogen oxides mass was more than 16 times higher when the diesel engine started $(1.103 \mathrm{~g})$ than when started the gasoline engine $(0.034 \mathrm{~g})$. The smallest difference in the measurement of exhaust compounds for two different engines occurred when comparing the number of particles. In this case, it was found that after the engine operating time from the cold start phase of $300 \mathrm{~s}$, the larger number of particles was emitted by a vehicle equipped with a diesel engine $\left(2.2 \cdot 10^{8}\right)$, for the gasoline engine the value of particles number was $1.4 \cdot 10^{8}$.
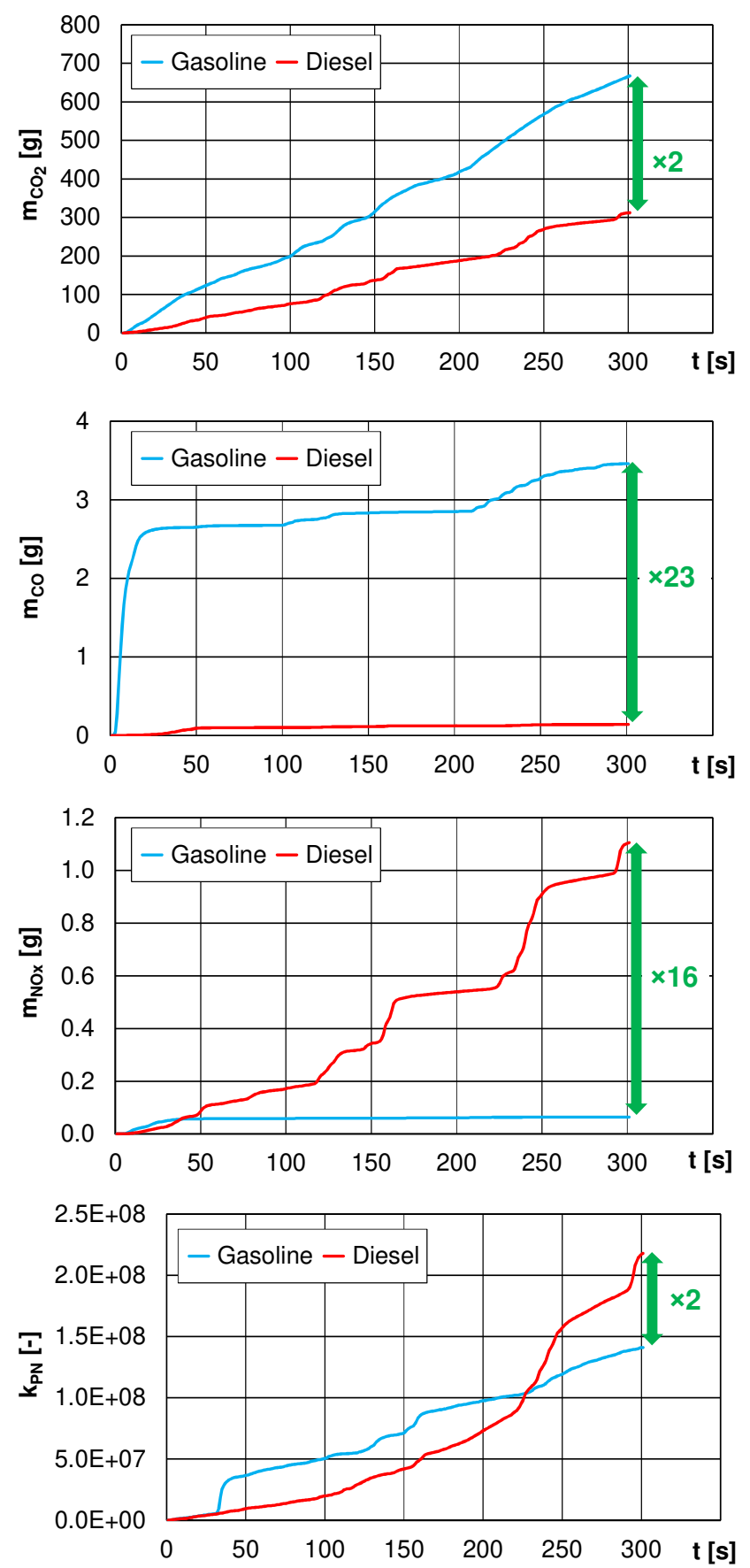

Fig. 11. The mass of carbon dioxide, carbon monoxide, nitrogen oxides and the number of particles in the cold start period of $300 \mathrm{~s}$ for gasoline and diesel engines

The presented data were used to determine the road emissions (converting the mass per unit of the road) during the cold start phase (lasting $300 \mathrm{~s}$ ) and the entire urban phase.

When comparing the results of the exhaust emissions to a vehicle equipped with a gasoline engine, it follows that (Fig. 12): 
- carbon dioxide road emissions in the cold start phase $(304 \mathrm{~g} / \mathrm{km})$ is higher by $51 \%$ than in the entire urban phase of the RDE test $(202 \mathrm{~g} / \mathrm{km})$,

- carbon monoxide road emissions in the cold start phase $(155 \mathrm{mg} / \mathrm{km})$ is higher by $64 \%$ than in the entire urban phase of the RDE test $(65 \mathrm{mg} / \mathrm{km})$,

- nitrogen oxides road emission in the cold start phase $(20.5 \mathrm{mg} / \mathrm{km})$ is higher by $89 \%$ than in the entire urban phase of the RDE test $(10.9 \mathrm{mg} / \mathrm{km})$,

- the number of particles in the cold start phase $\left(1.5 \cdot 10^{10}\right.$ $1 / \mathrm{km}$ ) is higher by $182 \%$ than in the entire urban phase of the RDE test $\left(5.2 \cdot 10^{9} 1 / \mathrm{km}\right)$.
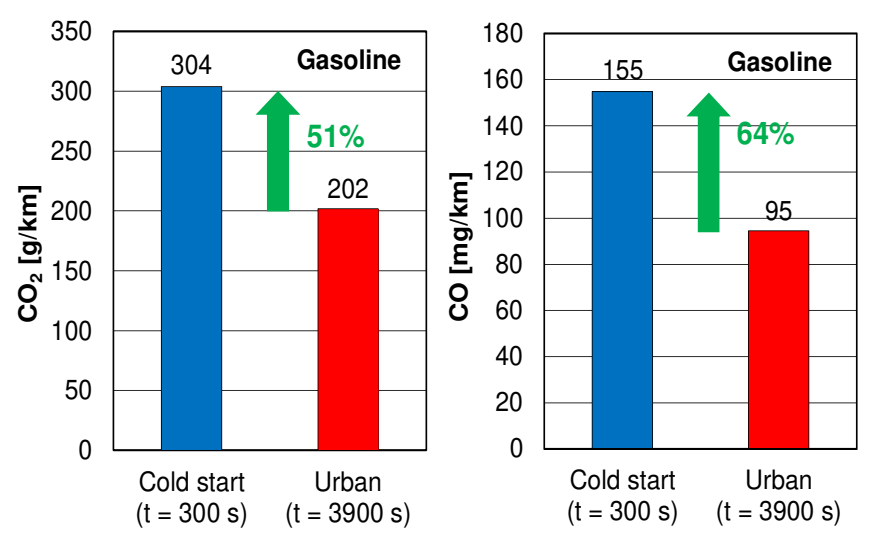

The changes in road emissions of individual exhaust compounds during the cold start phase of the diesel engine in relation to the whole part of the urban phase of RDE test are as follows (Fig. 13):

- carbon dioxide road emissions is higher by $70 \%$ (341 $\mathrm{g} / \mathrm{km}$ and $200 \mathrm{~g} / \mathrm{km}$ respectively),

- carbon monoxide road emissions is lower by $12 \%$ (119 $\mathrm{mg} / \mathrm{km}$ and $135 \mathrm{mg} / \mathrm{km}$ respectively),

- nitrogen oxides road emission is higher by $7 \%(42.3$ $\mathrm{mg} / \mathrm{km}$ and $39.5 \mathrm{mg} / \mathrm{km}$ respectively),

- number of particles is higher by $82 \%\left(5.1 \cdot 10^{11} 1 / \mathrm{km}\right.$ and $2.8 \cdot 10^{11} 1 / \mathrm{km}$ respectively).

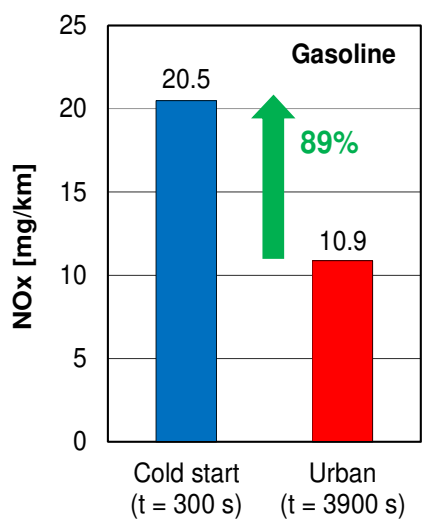

Fig. 12. Road emissions of carbon dioxide, carbon monoxide, nitrogen oxides and particles number during cold start of gasoline engine
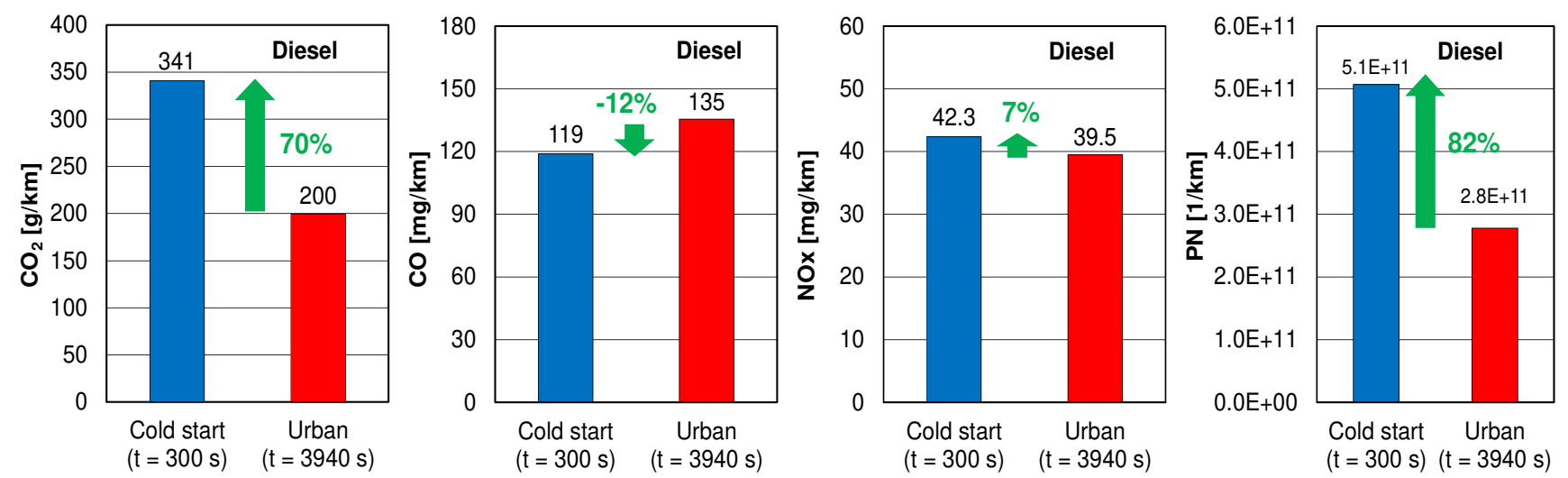

Fig. 13. Road emissions of carbon dioxide, carbon monoxide, nitrogen oxides and particles number during cold start of diesel engine

Comparing the cold start phase for different engine types in the urban part of the RDE test and in the entire RDE test it was found that:

- for gasoline engine (Fig. 14):

- the share of carbon dioxide emissions during the cold start $(300 \mathrm{~s})$ in relation to the urban part of the RDE test is $9.8 \%$, and in the relation to the entire RDE test it decreases to $3.4 \%$,

- the share of carbon monoxide emissions during the cold start $(300 \mathrm{~s})$ in relation to the urban part of RDE test is $10.65 \%$, and in the relation to the entire RDE test it decreases to $4.63 \%$,

- the share of nitrogen oxides emission during the cold start (300 s) in relation to the urban part of RDE test is $12.26 \%$, and in the relation to the entire RDE test it decreases to $3.42 \%$,

- the share of particles number emissions during the cold start (300 s) in relation to the urban part of RDE test is $18.37 \%$, and in the relation to the entire RDE test it decreases to $0.05 \%$,

- for diesel engine (Fig. 15):

- the share of carbon dioxide emissions during the cold start $(300 \mathrm{~s})$ in relation to the urban part of RDE test is $11.17 \%$, and in the relation to the entire RDE test it decreases to $3.98 \%$,

- the share of carbon monoxide emissions during the cold start $(300 \mathrm{~s})$ in relation to the urban part of RDE test is $5.57 \%$, and in the relation to the entire RDE test it increases to $8.19 \%$, 
- the share of nitrogen oxides emission during the cold start $(300 \mathrm{~s})$ in relation to the urban part of RDE test is $7.02 \%$, and in the relation to the entire RDE test it decreases to $2.95 \%$,
- the share of particles number emissions during the cold start $(300 \mathrm{~s})$ in relation to the urban part of RDE test is $11.94 \%$, and in the relation to the entire RDE test it decreases to $4.55 \%$

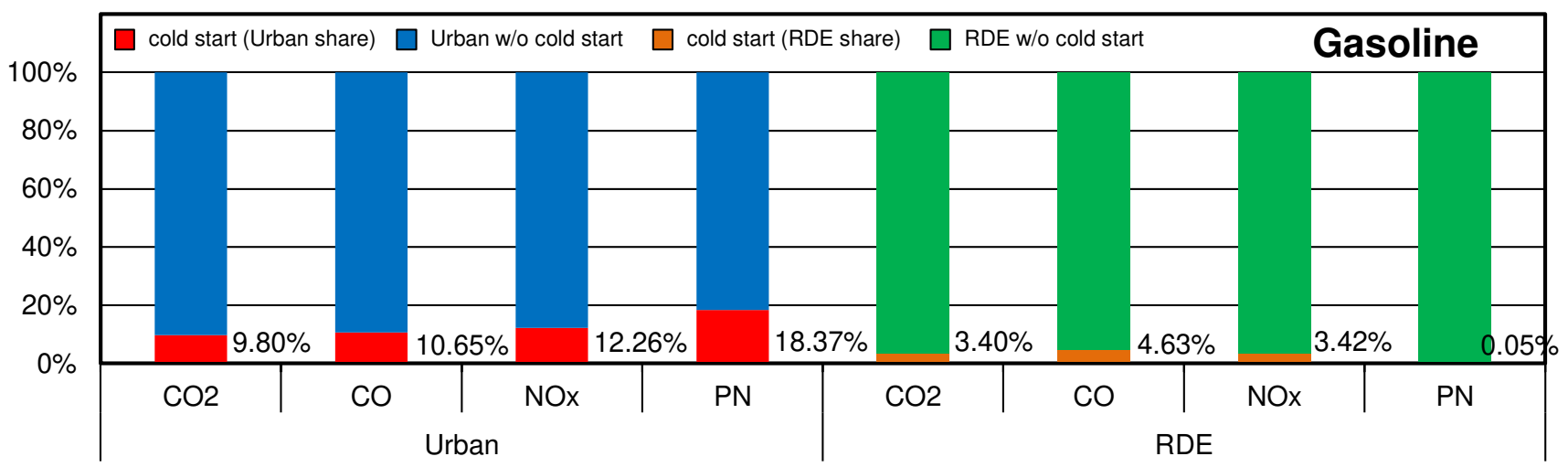

Fig. 14. The share of emissions exhaust compounds during the cold start (300 s) in relation to the urban part of RDE test and the entire RDE test for gasoline engine

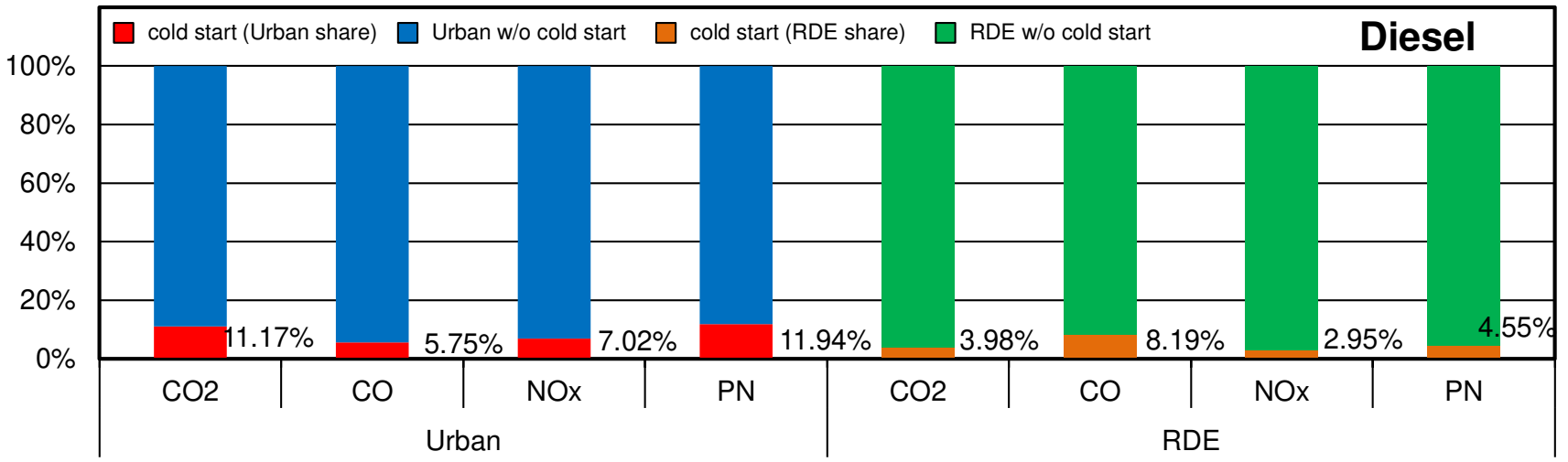

Fig. 15. The share of emissions exhaust compounds during the cold start ( $300 \mathrm{~s})$ in relation to the urban part of RDE test and the entire RDE test for diesel engine

\section{Summary}

Package 3 extended the RDE test procedure by introducing the inclusion of cold start period emissions in the whole value of exhaust emissions. It resulted in an increase of road exhaust emissions. This is mainly due to the warming of exhaust aftertreatment system, and at the same time to the pressure to reduce the exhaust emissions as much as possible in the first period after the cold start.
In the RDE test during cold start phase $(300 \mathrm{~s}$ period considered) the vehicle with a diesel engine in relation to the gasoline engine is characterized by:

- 2 times lower mass of carbon dioxide (and thus fuel consumption),

- 23 times lower mass of carbon monoxide,

- 16 times higher mass of nitrogen oxides,

- 2 times higher number of particles.

\section{Nomenclature}

a acceleration

$\mathrm{a}_{+} \quad$ positive acceleration

b road exhaust emissions value

CF conformity factor

EOBD European on-board diagnostic

EU European Union

Euro emission standard

GPS global positioning system
PEMS portable emission measurement system

PN particle number

RDE real driving emissions

RPA relative positive acceleration

$\mathrm{S}$ distance

u share

WLTC worldwide harmonized light vehicles test cycle V velocity 


\section{Bibliography}

[1] BIELACZYC, P., SZCZOTKA, A., WOODBURN, J. The effect of a low ambient temperature on the cold-start emissions and fuel consumption of passenger cars. $J$ Automobile Eng. 2011, 225(9), 1253-1264.

[2] Commission Regulation (EU) 692/2008 of 18 July 2008 implementing and amending Regulation (EC) 715/2007 of the European Parliament and of the Council on typeapproval of motor vehicles with respect to emissions from light passenger and commercial vehicles (Euro 5 and Euro 6) and on access to vehicle repair and maintenance information, European Commission (EC), Official J. European Union, L 199.

[3] Commission Regulation (EU) 2016/427 of 10 March 2016 amending Regulation (EC) No 692/2008 as regards emissions from light passenger and commercial vehicles (Euro 6).

[4] Commission Regulation (EU) 2016/646 of 20 April 2016 amending Regulation (EC) No 692/2008 as regards emissions from light passenger and commercial vehicles (Euro 6).

[5] Commission Regulation (EU) 2017/1151 of 1 June 2017 supplementing Regulation (EC) No 715/2007 of the European Parliament and of the Council on type-approval of motor vehicles with respect to emissions from light passenger and commercial vehicles (Euro 5 and Euro 6) and on access to vehicle repair and maintenance information, amending $\mathrm{Di}$ rective 2007/46/EC of the European Parliament and of the Council, Commission Regulation (EC) No 692/2008 and Commission Regulation (EU) No 1230/2012 and repealing Commission Regulation (EC) No 692/2008.

[6] Commission Regulation 2017/1154 of 7 June 2017 amending Regulation (EU) 2017/1151 supplementing Regulation (EC) No 715/2007 of the European Parliament and of the Council on type-approval of motor vehicles with respect to emissions from light passenger and commercial vehicles (Euro 5 and Euro 6) and on access to vehicle repair and maintenance information, amending Directive 2007/46/EC of the European Parliament and of the Council, Commission Regulation (EC) No 692/2008 and Commission Regulation (EU) No 1230/2012 and repealing Regulation (EC) No 692/2008 and Directive 2007/46/EC of the European Parliament and of the Council as regards real-driving emissions from light passenger and commercial vehicles (Euro 6) OJ L 175, 7.7.2017.

[7] DARDiOTIS, C., MARTINI, G., MAROTTA, A. et al. Low-temperature cold-start gaseous emissions of late technology passenger cars. Applied Energy. 2013, 111, 468-478.

Prof. Jacek Pielecha, DSc., DEng. - Faculty of
Transport Engineering, Poznan University of Tech-
nology.
e-mail: jacek.pielecha@ put.poznan.pl
[8] FONTARAS, G., FRANCO, V., DILARA, P. et al. Development and review of Euro 5 passenger car emission factors based on experimental results over various driving cycles. Science of the Total Environment. 2014, 468-469, 10341042.

[9] MAY, J., FAVRE, C., BOSTEELS, D. Emissions from Euro 3 to Euro 6 light-duty vehicles equipped with a range of emissions control technologies. Association for Emissions Control by Catalyst. London 2013.

[10] MERKISZ, J., PIELECHA, J., LIJEWSKI, P. et al. Exhaust emissions from vehicles in real traffic conditions in the Poznan agglomeration. 2st International conference on modelling, monitoring and management of air pollution. WIT Transactions on Ecology and the Environment. 2013, 174, 27-38.

[11] PIELECHA, J., PIELECHA, I., GIS, W., KURTYKA, K. Cold start emissions of passenger cars in Real Driving Emissions tests. 2019 (to be published).

[12] PIELECHA, J., MAGDZIAK, A., BRZEZINSKI, L. Nitrogen oxides emission evaluation for Euro 6 category vehicles equipped with combustion engines of different displacement volume. IOP Conf Ser Earth Environ Sci. 2019, 214, 012010.

[13] PIELECHA, J., MERKISZ, J., MARKOWSKI, J. et al., Analysis of passenger car emission factors in RDE tests. 1st International conference on the sustainable energy and environment development (SEED 2016). E3S Web of Conferences. 2016, 10, 00073.

[14] SUARES-BERTOA, R., ASTORGA, C. Impact of cold temperature on Euro 6 passenger car emissions. Environmental Pollution. 2018, 234, 318-329.

[15] TRIANTAFYLlOPOULOS, G., KATSAOUNIS, D., KARAMITROS, D. et al. Experimental assessment of the potential to decrease diesel $\mathrm{NO}_{\mathrm{x}}$ emissions beyond minimum requirements for Euro 6 Real Drive Emissions (RDE) compliance. Sci Total Environ. 2018, 618, 1400-1407.

[16] WEISS, M., PAFFUMI, E., CLAIROTTE, M. et al. Including cold-start emissions in the Real-Driving Emissions (RDE) test procedure. Publications Office of the European Union. 2017.

[17] ZHAO, Q. Electromobility research in Germany and China: structural differences. Scientometrics. 2018, 117, 473-493.

Karolina Kurtyka, MEng. - Faculty of Transport Engineering, Poznan University of Technology. e-mail:

karolina.t.kurtyka@doctorate.put.poznan.pl

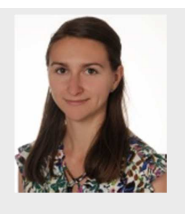

Kinga Skobiej, Eng. - Faculty of Transport Engineering, Poznan University of Technology. e-mail:kinga.skobiej@student.put.poznan.pl
Prof. Jerzy Merkisz, DSc., DEng. - Faculty of nology.

e-mail: jerzy.merkisz@put.poznan.pl

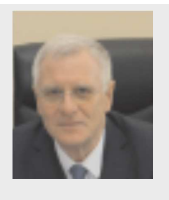

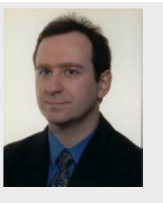

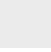

